\title{
NR4A2 Mutations Can Cause Intellectual Disability and Language Impairment With Persistent Dystonia-Parkinsonism
}

\author{
Silvia Jesús, MD, PhD,* Isabel Hinarejos, MSc,* Fátima Carrillo, MD, PhD, Dolores Martínez-Rubio, PhD, \\ Daniel Macías-García, MD, Ana Sánchez-Monteagudo, PhD, Astrid Adarmes, MD, Vincenzo Lupo, PhD, \\ Belén Pérez-Dueñas, MD, PhD, Pablo Mir, MD, PhD,* and Carmen Espinós, PhD*
}

Neurol Genet 2021;7:e543. doi:10.1212/NXG.0000000000000543

The NR4A2/NURR1 gene (MIM*601828) has recently been associated with autosomal-dominant early-onset dystonia-parkinsonism with intellectual disability. ${ }^{1}$ NR4A2 codifies for a nuclear transcription factor and is expressed mainly in the substantia nigra, ventral tegmental area, and limbic areas. $^{2}$ To date, 14 different alterations in NR4A2 have been described associated with various clinical phenotypes, mainly with neurodevelopment disorders (table e-1, links.lww.com/NXG/ A371). We describe here an interesting case suffering a persistent dystonia-parkinsonism syndrome (DPS) with motor tics, which expands the clinical phenotype of NR4A2-associated DPS.

This is a 30-year-old man with no family history of neurologic disease who was born after a normal pregnancy and childbirth. He started walking with support at 13 months, but his gait was clumsy, resulting in numerous falls during childhood. At 2 years old, the patient presented attention deficit. He began to speak at 3 years of age but with impaired fluency, vocabulary, and articulation. The patient required special education to learn basic writing and arithmetic skills. At the age of 7 years, his intelligence quotient was 77 . At 16 years old, he presented trichotillomania, and he began to experience motor tics characterized by an urge to move his right shoulder upward, an urge that was relieved after performing the movement. He was satisfactorily treated with atomoxetine. He also noticed an abnormal backward-cervical deviation. This clinical situation remained stable for 10 years, although motor tics tended to improve with age.

At 28 years old, the patient complained of slowness, walking difficulties, and a worsening abnormal craniocervical posture. He presented marked jaw-opening dystonia and parkinsonian features, with rigidity and a progressive reduction in the amplitude and frequency of repetitive movements in the left hemibody. The gait difficulties manifested with dragging steps, mainly in the left hemibody (Video 1). The patient also presented nonmotor symptoms such as gastrointestinal and sleep-related symptoms, with the mobility and communication domains affecting his quality of life the most (figures e-1 and e-2, links.lww.com/NXG/A371).

The results of supplementary and neuroimaging tests were normal (figure 1, table e-2, links. lww.com/NXG/A371), whereas ${ }^{123}$ FP-CIT-single photon emission CT revealed reduced bilateral (predominantly right sided) uptake in both striatum (figure e-1).

A genetic analysis using a custom gene panel of 498 genes involved in movement disorders (MovDisord-498) ${ }^{3}$ revealed no causative mutations (appendix e-1, links.lww.com/NXG/ A371). The proband and healthy parents (trio) then underwent whole exome sequencing

\author{
Correspondence \\ Dr. Mir \\ pmir@us.es \\ or Dr. Espinós \\ cespinos@cipf.es
}

MORE ONLINE

○ Video

*These authors contributed equally to this work.

From the Unidad de Trastornos del Movimiento (S.J., F.C., D.M.-G., A.A., P.M.), Servicio de Neurología y Neurofisiología Clínica, Instituto de Biomedicina de Sevilla, Hospital Universitario Virgen del Rocío/CSIC/Universidad de Sevilla, Spain; Centro de Investigación Biomédica en Red Enfermedades Neurodegenerativas (CIBERNED) (S.J., F.C., D.M.-G., A.A., P.M.), Spain; Unit of Genetics and Genomics of Neuromuscular and Neurodegenerative Disorders (I.H., D.M.-R., A.S.-M., V.L., C.E.), Centro de Investigación Príncipe Felipe (CIPF), Valencia, Spain; Joint Units INCLIVA and IIS La Fe Rare Diseases (I.H., D.M.-R., A.S.-M., V.L., C.E.), Centro de Investigación Príncipe Felipe (CIPF), Valencia, Spain; Department of Pediatric Neurology (B.P.-D.), Hospital Universitari Vall d'Hebron, Barcelona, Spain; and Universitat Autònoma de Barcelona (B.P.-D.), Spain. 

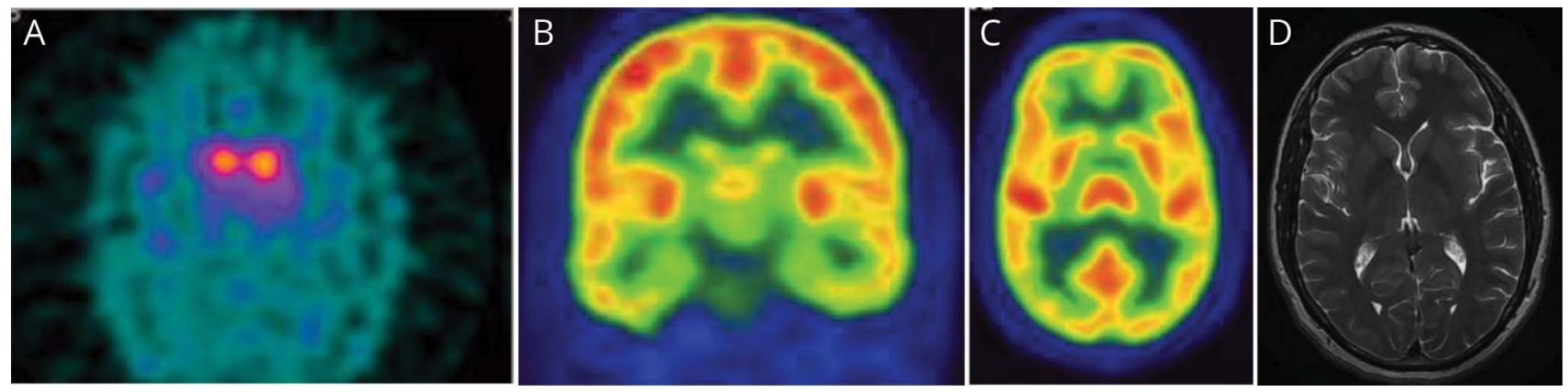

(A) ${ }^{123} \mathrm{FP}-\mathrm{CIT}$-SPECT revealed bilateral uptake reduction with impairment of the caudate and putamen and a predominance in the right hemisphere and both putamen. (B and C) Normal ${ }^{18}$ FDG-PET coronal and axial images. (D) Normal cranial MRI T2 axial image. ${ }^{18}$ FDG $=18$-fluorodeoxyglucose.

(WES) using the Whole Exome Family Plus test (Blueprint Genetics, Helsinki, Finland). WES data were filtered as previously described ${ }^{4}$ and 3 candidate disease-causing changes were found (table e-3). We further investigated the detected changes by Sanger sequencing in all the available relatives (figure e-3). The KCNQ2 c.1807-5A>T resulted to be a falsepositive result. The proband, his parents, and his brother carried the CEP170 c.2375C >A (p.S792*) change in heterozygosis, and therefore, this variant was discarded as diseasecausing mutation. Regarding the NR4A2 c.956G>A (p.R319Q) substitution, only the patient harbored it, and consequently, this mutation was de novo. Moreover, 2 frameshift mutations in NR4A2 were recently described in 2 patients with DPS. ${ }^{1} \mathrm{R} 319$ is an evolutionarily conserved amino acid (data not shown) located on the essential domain Zf-C4/DBD (figure e-4). The variant was considered likely pathogenic according to the American College of Medical Genetics and Genomics classification, based mainly on the PS2 and PM2 criteria, although the NR4A2 c.956G >A mutation also meets the PP3 and PM1 criteria. ${ }^{5}$

Consistent with previous descriptions of NR4A2 subjects, ${ }^{1}$ our patient also presented craniocervical dystonia with parkinsonian features that started in early adulthood, with previous intellectual disability and language impairment. In our proband, however, the dystonia was persistent and worsened in stressful situations, contrasting with the previously reported paroxysmal dystonic episodes. ${ }^{1}$ Clinicians should therefore be aware of paroxysmal and persistent dystonia features related to NR4A2.

Our proband also shared with previously reported cases, clear signs, and symptoms of dopaminergic degeneration, ${ }^{1}$ suggesting a relationship between the role of NR4A2 and dysfunction of the dopaminergic nigrostriatal network. Of interest, our patient also experienced motor tics and attention deficit during childhood. Previous reports have shown the involvement of gross deletions in NR4A2 in autism spectrum disorders, with some patients manifesting "restlessness" during childhood. ${ }^{6}$ To date, however, there have been no reported data on the comorbidity with motor tics, which are therefore a novel feature associated with the NR4A2 phenotype, a feature that will become clearer as more cases are reported.

In NR4A2, there seems to be no association between the mutation type and the resulting phenotype, except for patients with complex neurodevelopmental disorders that are caused by large deletions. In fact, diverse NR4A2-related phenotypes can even be caused by the same mutation. ${ }^{7}$ In this case study, we presented the first patient with DPS caused by a missense NR4A2 mutation, the p.R319Q. NR4A2-associated DPS can therefore be caused by more than just loss-offunction mutations.

In conclusion, motor tics and persistent dystonia in NR4A2associated DPS should be included within its phenotypic description along with early-onset parkinsonism and intellectual disability with language impairment. The description of new cases may help to improve the correlation between NR4A2 and its clinical picture, which, so far, is mainly relevant for neurodevelopmental disorders.

\section{Study Funding}

This work was supported by the Health Institute Carlos III-General Subdirectorate for Research Evaluation and Promotion (PI16/01575, PI18/01898, PI18/00147, PI19/ 01576), the Spanish Ministry of Economy and Competitiveness (SAF2007-60700), the Ministry of Economy, Innovation, Science and Business of the Government of Andalucía (CVI-02526, CTS-7685), the Ministry of Health and Social Welfare of the Government of Andalucía (PI-04592018, PE-0210-2018, PE-0186-2019) and by the Valencian Government (PROMETEO/2018/135), within the framework of the National Research and Development Plan cofunded with European Regional Development Funds. Part of the equipment employed in this study was funded by the Valencian Government and co-financed with European Regional Development Funds (OP ERDF of Valencian Community 2014-2020). I. Hinarejos has a PFIS-PhD fellowship (FI19/00072), S. Jesús has a contract "Acción B Clínicos- 
Investigadores" (Action B Clinicians-Researchers) contract (B0007-2019) funded by the Ministry of Health and Family of the Government of Andalucía, and D. Macías-García has a Río Hortega contract (CM18/00142) funded by the Health Institute Carlos III.

\section{Disclosure}

$\mathrm{S}$. Jesús has received honoraria from AbbVie, Bial, Merz, UCB, Italfarmaco and Zambon. F. Carrillo has received honoraria from AbbVie, Bial, and Zambon. A. Adarmes has received honoraria from AbbVie and Italfarmaco. D. Macías-García has received honoraria from AbbVie. $\mathrm{P}$. Mir has received honoraria from AbbVie, Abbott, Allergan, Bial, Merz, UCB, and Zambon. All other authors report no conflicts of interest. Go to Neurology.org/NG for full disclosures.

\section{Publication History}

Received by Neurology: Genetics July 18, 2020. Accepted in final form November 6, 2020.

\section{Appendix Authors}

\begin{tabular}{|c|c|c|}
\hline Name & Location & Contribution \\
\hline $\begin{array}{l}\text { Silvia Jesús, } \\
\text { MD, PhD }\end{array}$ & $\begin{array}{l}\text { Biomedical Institute of } \\
\text { Seville/University Hospital } \\
\text { Virgen del Rocío, Spain }\end{array}$ & $\begin{array}{l}\text { Clinically described and } \\
\text { supervised the patients. } \\
\text { Wrote the study/first draft. } \\
\text { Reviewed and critiqued } \\
\text { the manuscript. }\end{array}$ \\
\hline
\end{tabular}

\begin{tabular}{ll}
\hline Isabel & Research Centre Príncipe \\
Hinarejos, & Felipe (CIPF), Valencia, \\
MSc & Spain
\end{tabular}

Performed/interpreted the genetic study. Wrote the study/first draft. Reviewed and critiqued the manuscript.

\begin{tabular}{lll}
\hline $\begin{array}{l}\text { Fátima } \\
\text { Carrillo, MD, } \\
\text { PhD }\end{array}$ & $\begin{array}{l}\text { Biomedical Institute of } \\
\text { Seville/University Hospital } \\
\text { Virgen del Rocío, Spain }\end{array}$ & $\begin{array}{l}\text { Clinically described and } \\
\text { supervised the patients. } \\
\text { Reviewed and critiqued } \\
\text { the manuscript. }\end{array}$ \\
\hline $\begin{array}{l}\text { Dolores } \\
\text { Martínez- } \\
\text { Rubio, MSc }\end{array}$ & $\begin{array}{l}\text { Research Centre Príncipe } \\
\text { Felipe (CIPF), Valencia, } \\
\text { Spain }\end{array}$ & $\begin{array}{l}\text { Conceived and designed } \\
\text { the study. Performed/ } \\
\text { interpreted the genetic } \\
\text { study. Reviewed and } \\
\text { critiqued the manuscript. }\end{array}$ \\
\hline $\begin{array}{l}\text { Daniel } \\
\text { Macías- } \\
\text { García, MD }\end{array}$ & $\begin{array}{l}\text { Biomedical Institute of } \\
\text { Seville/University Hospital }\end{array}$ & $\begin{array}{l}\text { Clinically described and } \\
\text { Supervised the patients. } \\
\text { Reviewed and critiqued } \\
\text { the manuscript. }\end{array}$ \\
\hline
\end{tabular}

Appendix (continued)

\begin{tabular}{|c|c|c|}
\hline Name & Location & Contribution \\
\hline $\begin{array}{l}\text { Ana Sánchez- } \\
\text { Monteagudo, } \\
\text { MSc }\end{array}$ & $\begin{array}{l}\text { Research Centre Príncipe } \\
\text { Felipe (CIPF), Valencia, } \\
\text { Spain }\end{array}$ & $\begin{array}{l}\text { Performed/interpreted } \\
\text { the genetic study. } \\
\text { Reviewed and critiqued } \\
\text { the manuscript. }\end{array}$ \\
\hline $\begin{array}{l}\text { Astrid } \\
\text { Adarmes, MD }\end{array}$ & $\begin{array}{l}\text { Biomedical Institute of } \\
\text { Seville/University Hospital } \\
\text { Virgen del Rocío, Spain }\end{array}$ & $\begin{array}{l}\text { Clinically described and } \\
\text { supervised of patients. } \\
\text { Reviewed and critiqued } \\
\text { the manuscript. }\end{array}$ \\
\hline $\begin{array}{l}\text { Vincenzo } \\
\text { Lupo, PhD }\end{array}$ & $\begin{array}{l}\text { Research Centre Príncipe } \\
\text { Felipe (CIPF), Valencia, } \\
\text { Spain }\end{array}$ & $\begin{array}{l}\text { Conceived and designed } \\
\text { the study. Performed/ } \\
\text { interpreted the genetic } \\
\text { study. Reviewed and } \\
\text { critiqued the manuscript. }\end{array}$ \\
\hline $\begin{array}{l}\text { Belén Pérez- } \\
\text { Dueñas, MD, } \\
\text { PhD }\end{array}$ & $\begin{array}{l}\text { Hospital Universitari Vall } \\
\text { d'Hebron, Barcelona, } \\
\text { Spain }\end{array}$ & $\begin{array}{l}\text { Conceived and designed } \\
\text { the study. Reviewed and } \\
\text { critiqued the manuscript. }\end{array}$ \\
\hline $\begin{array}{l}\text { Pablo Mir, } \\
\text { MD, PhD }\end{array}$ & $\begin{array}{l}\text { Biomedical Institute of } \\
\text { Seville/University Hospital } \\
\text { Virgen del Rocío, Spain }\end{array}$ & $\begin{array}{l}\text { Clinically described and } \\
\text { supervised the patients. } \\
\text { Wrote the study/first draft. } \\
\text { Reviewed and critiqued } \\
\text { the manuscript. }\end{array}$ \\
\hline $\begin{array}{l}\text { Carmen } \\
\text { Espinós, PhD }\end{array}$ & $\begin{array}{l}\text { Research Centre Príncipe } \\
\text { Felipe (CIPF), Valencia, } \\
\text { Spain }\end{array}$ & $\begin{array}{l}\text { Conceived and designed } \\
\text { the study. Performed/ } \\
\text { interpreted the } \\
\text { genetic study. Wrote the } \\
\text { study/first draft. } \\
\text { Reviewed and critiqued } \\
\text { the manuscript. }\end{array}$ \\
\hline
\end{tabular}

\section{References}

1. Wirth T, Mariani LL, Bergant G, et al. Loss-of-function mutations in NR4A2 cause dopa-responsive dystonia Parkinsonism. Mov Disord 2020;35:880-885.

2. Sakurada K, Ohshima-Sakurada M, Palmer TD, Gage FH. Nurrl, an orphan nuclear receptor, is a transcriptional activator of endogenous tyrosine hydroxylase in neural progenitor cells derived from the adult brain. Development 1999;126:4017-4026.

3. Correa-Vela M, Lupo V, Montpeyo M, et al. Impaired proteasome activity and neurodegeneration with brain iron accumulation in FBXO7 defect. Ann Clin Transl Neurol 2020;7:1436-1442.

4. Sanchez-Monteagudo A, Alvarez-Sauco M, Sastre I, et al. Genetics of Wilson disease and Wilson-like phenotype in a clinical series from eastern Spain. Clin Genet 2020;97: 758-763.

5. Richards S, Aziz N, Bale S, et al. Standards and guidelines for the interpretation of sequence variants: a joint consensus recommendation of the American College of medical Genetics and Genomics and the Association for Molecular Pathology. Genet Med 2015; 17:405-424.

6. Levy J, Grotto S, Mignot C, et al. NR4A2 haploinsufficiency is associated with intellectual disability and autism spectrum disorder. Clin Genet 2018;94:264-268.

7. Ramos LLP, Monteiro FP, Sampaio LPB, et al. Heterozygous loss of function of NR4A2 is associated with intellectual deficiency, rolandic epilepsy, and language impairment. Clin Case Rep 2019;7:1582-1584. 


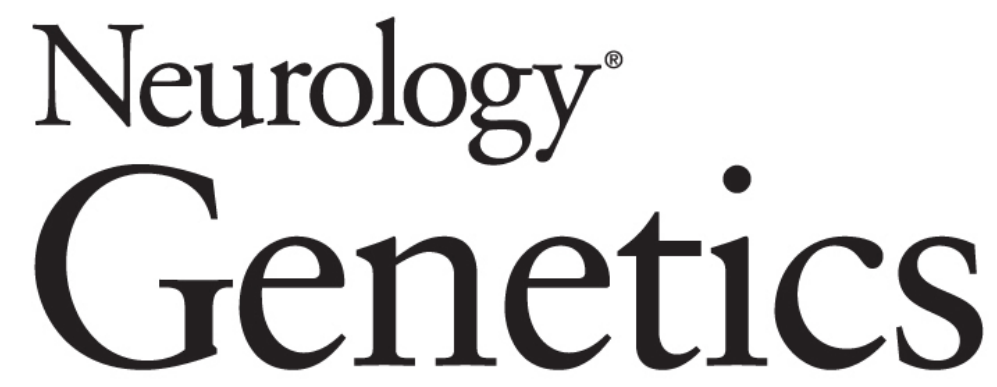

NR4A2 Mutations Can Cause Intellectual Disability and Language Impairment With Persistent Dystonia-Parkinsonism

Silvia Jesús, Isabel Hinarejos, Fátima Carrillo, et al. Neurol Genet 2021;7;

DOI 10.1212/NXG.0000000000000543

This information is current as of January 21, 2021

Neurol Genet is an official journal of the American Academy of Neurology. Published since April 2015, it is an open-access, online-only, continuous publication journal. Copyright Copyright ( 2021 The Author(s). Published by Wolters Kluwer Health, Inc. on behalf of the American Academy of Neurology.. All rights reserved. Online ISSN: 2376-7839.

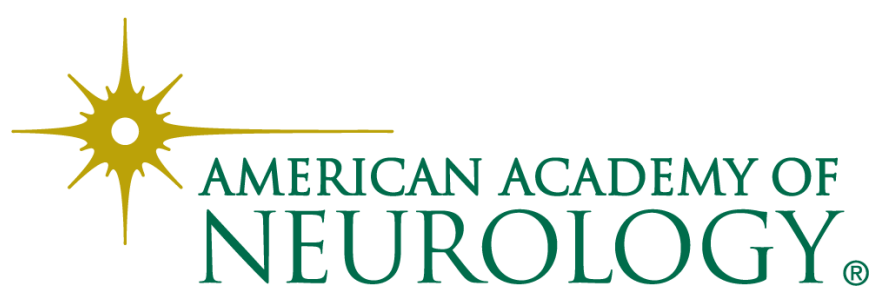




\section{Updated Information \& Services}

References

Citations

Subspecialty Collections

Permissions \& Licensing

\section{Reprints}

including high resolution figures, can be found at: http://ng.neurology.org/content/7/1/e543.full.html

This article cites 7 articles, 1 of which you can access for free at: http://ng.neurology.org/content/7/1/e543.full.html\#\#ref-list-1

This article has been cited by 1 HighWire-hosted articles: http://ng.neurology.org/content/7/1/e543.full.html\#\#otherarticles

This article, along with others on similar topics, appears in the following collection(s):

\section{Clinical neurology examination}

http://ng.neurology.org//cgi/collection/clinical_neurology_examination

\section{Dystonia}

http://ng.neurology.org//cgi/collection/dystonia

Genetic linkage

http://ng.neurology.org//cgi/collection/genetic_linkage

\section{Parkinson's disease/Parkinsonism}

http://ng.neurology.org//cgi/collection/parkinsons_disease_parkinsonis $\mathrm{m}$

Tics

http://ng.neurology.org//cgi/collection/tics

Information about reproducing this article in parts (figures,tables) or in its entirety can be found online at:

http://ng.neurology.org/misc/about.xhtml\#permissions

Information about ordering reprints can be found online: http://ng.neurology.org/misc/addir.xhtml\#reprintsus

Neurol Genet is an official journal of the American Academy of Neurology. Published since April 2015, it is an open-access, online-only, continuous publication journal. Copyright Copyright $\odot 2021$ The Author(s). Published by Wolters Kluwer Health, Inc. on behalf of the American Academy of Neurology.. All rights reserved. Online ISSN: 2376-7839.

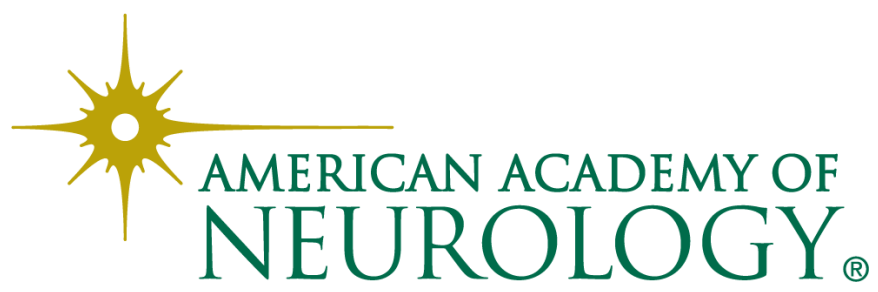

